\title{
Adenosine treatment augments random flap survival in rats
}

\author{
Aydin Saray MD ${ }^{1}$, Alpaslan Apan $\mathrm{MD}^{2}$, Ali Teoman Tellioglu MD ${ }^{1}$ \\ Departments of ${ }^{1}$ Plastic Surgery and ${ }^{2}$ Anaesthesiology, Kirikkale University Medical School, Kirikkale, \\ Turkey
}

\section{A Saray, A Apan, AT Tellioglu. Adenosine treatment augments random flap survival in rats. Can J Plast Surg 2001;9(5):193-197.}

Adenosine and purine nucleosides are intermediates in the pathway of purine nucleotide degradation. Adenosine causes vasodilation in all arterioles, except those in the kidney, and is the major regulator of coronary blood flow. The objective of the present study was to investigate the efficacy and role of 9-beta-D-ribofuranosyl adenosine (RFA), a derivative of adenosine, for the augmentation of random flap survival in rats. Varying doses of adenosine and a nonselective adenosine antagonist, 8-phenyltheophylline, were administered before elevation of $3 \times 10 \mathrm{~cm}$ dorsal random flaps in 60 rats. The rats were randomly assigned to five groups and received the following treatment: group I (controls) was treated with placebo (saline, $1 \mathrm{~mL} /$ day); group II was treated with RFA $25 \mu \mathrm{g} / \mathrm{kg} / \mathrm{day}$; group III was treated with RFA $50 \mu \mathrm{g} / \mathrm{kg} /$ day; group IV was treated with RFA $100 \mu \mathrm{g} / \mathrm{kg} /$ day; and group V was treated with 8-phenyltheophylline (10 mg/kg/day). All daily injections were given intravenously for seven days. Flap survival was assessed on day 8 . Therapeutic and higher doses of adenosine-treated flaps showed a significant increase in viability compared with saline-treated flaps in the control group, while there was no improvement in flap survival with low dose adenosine. Phenyltheophylline reversed the beneficial effect of adenosine and increased flap necrosis, which was comparable with that of the controls. The findings show that adenosine can enhance flap survival, and this beneficial effect is possibly due to vasodilation, inhibition of noradrenalin release, reduction of energy consumption, inhibition of reactive oxygen species and a preconditioning effect; however, this effect seems to be dose-related. Adenosine is an easily available drug for clinical use in ischemic heart diseases and should be considered in potentially ischemic flaps.

Key Words: Adenosine; Flap survival; Theophylline

\section{Le traitement à l'adénosine prolonge la survie de lambeaux aléatoires chez le rat}

RÉSUMÉ : Les nucléosides de l'adénosine et de la purine sont des intermédiaires dans la voie de dégradation nucléosidique de la purine. L'adénosine provoque une vasodilatation de toutes les artérioles à l'exception de celles du rein, mais agit à titre d'important régulateur du débit cardiaque coronarien. L'objectif de la présente étude était de mesurer l'efficacité et le rôle de la 9-bêta-D-ribofuranosyl adénosine (RFA), un dérivé de l'adénosine, pour prolonger la survie d'un lambeau aléatoire chez le rat. Des doses diverses d'adénosine et de l'antagoniste non sélectif de l'adénosine, 8-phénylthéophylline, ont été administrées avant le soulèvement de lambeaux aléatoires dorsaux de $3 \mathrm{~cm}$ sur $10 \mathrm{chez} 60$ rats. Les rats ont été assignés aléatoirement à cinq groupes et ont respectivement reçu les traitements suivants : groupe I (témoins) placebo (solution physiologique, $1 \mathrm{~mL} /$ jour); groupe II, RFA $25 \mu \mathrm{g} / \mathrm{kg} /$ jour; groupe III RFA $50 \mu \mathrm{g} / \mathrm{kg} /$ jour; groupe IV, RFA $100 \mu \mathrm{g} / \mathrm{kg} /$ jour et groupe $\mathrm{V}$, 8-phénylthéophylline $(10 \mathrm{mg} / \mathrm{kg} / \mathrm{jour})$. Toutes les injections quotidiennes ont été administrées par voie intraveineuse pendant sept jours. La survie des lambeaux a été évaluée au jour 8. Les lambeaux traités avec les doses thérapeutiques et supérieures d'adénosine ont connu une augmentation significative de leur viabilité comparativement aux lambeaux traités par solution saline dans le groupe témoin, bien que l'on n'ait noté aucune amélioration de la survie des lambeaux avec les doses plus faibles d'adénosine. La phénylthéophylline a renversé les effets bénéfiques de l'adénosine et augmenté la nécrose des lambeaux qui s'est révélée comparable à celle des témoins. Les conclusions montrent que l'adénosine peut améliorer la survie des lambeaux; cet effet favorable est probablement dû à la vasodilatation, à l'inhibition de la libération de noradrénaline, à la réduction de la consommation d'énergie, à l'inhibition des espèces réagissant à l'oxygène et à un effet préconditionnant. Par contre, cet effet semble lié à la dose. L'adénosine est un médicament facilement accessible pour usage clinique dans les maladies cardiaques ischémiques et elle est à envisager dans les cas de lambeaux potentiellement ischémiques.

Correspondence: Dr Aydin Saray, Konutkent-1, B2 Blok, No 16, Cayyolu-06530, Ankara, Turkey. Telephone +90-312-241-2374,

fax+90-318-225-2819, e-mail adenosine@aydinsaray.8m.com 
$\mathrm{W}$ hile skin flaps are frequently used in surgical practice, the pathophysiology of their occasional failure is poorly understood. An increasing number of studies is devoted to the pharmacological manipulation of flaps, yet the exact physiological basis for the use of these agents is unsolved (1). Tremendous research efforts have been directed toward identifying pharmacological interventions for the augmentation of skin flap survival, and every surgeon would welcome an agent that minimizes the deleterious effects of ischemia or enhances the tolerance of the tissue under ischemic conditions. A recent trend in flap research is aimed at increasing the tolerance of the tissue to warm ischemia and attenuation of the necrosis (2-3).

Adenosine, which is derived from the metabolism of adenosine triphosphate (ATP), is a potent vasodilator that acts on specific receptors located on the outer surface of the smooth muscle cell (4-5). The nucleotides ATP, adenosine 5 '-diphosphate and adenosine monophosphate, and the nucleoside adenosine have been shown to induce coronary vasodilation and accumulate rapidly in large amounts in the ischemic myocardium (5). Adenosine is a very inexpensive and safe clinical drug, and it can be administered conveniently without any serious systemic effects (6). Several studies have reported that adenosine treatment attenuates infarct size in muscle flaps and displays the major role as the "trigger mediator' of acute ischemic preconditioning in skeletal muscle and in the heart (7-8).

Therefore, the objective of the present project was to investigate the efficacy of acute adenosine treatment for the attenuation of ischemic necrosis in random skin flaps in the rat.

\section{MATERIALS AND METHODS}

Sixty Wistar albino rats, weighing 275 to $375 \mathrm{~g}$, were used in the present study. The rats were anesthetized with intraperitoneal injections of ketamine $(50 \mathrm{mg} / \mathrm{kg}$ ) and xylazine $(5 \mathrm{mg} / \mathrm{kg})$. Borders of the random flaps were outlined on the

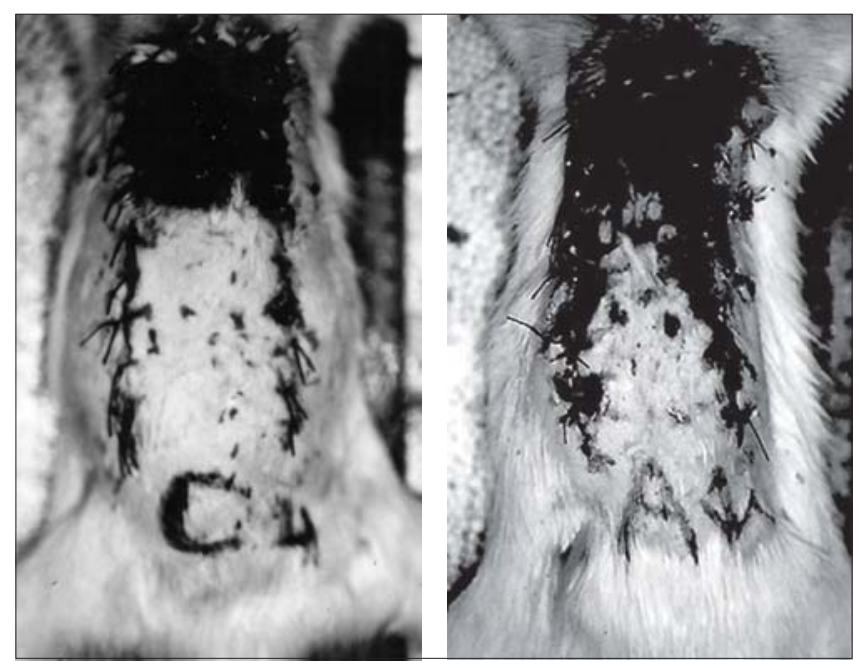

Figure 1) Left Photograph of a representative flap illustrating the regions of survival and necrosis from the control group of rats treated with saline. Right Increased necrosis noted in a representative flap treated with low dose adenosine back of the animals by using a flap template. Caudally based $3 \times 10 \mathrm{~cm}$ dorsal skin flaps were raised in rats, according to Khouri et al (9) and resutured to the original site with 4-0 silk sutures. No electrocautery or hemostatic agents were used. Each rat was housed in a separate cage at $22^{\circ} \mathrm{C}$ to prevent cannibalism, and had free access to water and food. The following agents were used: 9-beta-D-ribofuranosyl adenosine and 8-phenyltheophylline.

The rats were randomly assigned to five groups. Group I $(\mathrm{n}=12)$, the control group, was given saline $1 \mathrm{~mL} /$ day intravenously. Group II $(\mathrm{n}=12)$ received adenosine $25 \mu \mathrm{g} / \mathrm{kg} /$ day intravenously. Group III $(\mathrm{n}=12)$ received adenosine $50 \mu \mathrm{g} / \mathrm{kg} /$ day intravenously. Group IV $(\mathrm{n}=12)$ received adenosine $100 \mu \mathrm{g} / \mathrm{kg} /$ day intravenously. Group V (n=12) received 8-phenyltheophylline $10 \mathrm{mg} / \mathrm{kg} /$ day intravenously.

The first dose of all the drugs used in the present study was administered $10 \mathrm{~min}$ before elevation of the flaps. Three different doses of adenosine $(25,50$ and $100 \mu \mathrm{g} / \mathrm{kg})$ were chosen according to previous articles that reported a reduction in the infarct size by the aforementioned doses $(7,8,10,11)$. Injection of saline or adenosine was continued for one week postoperatively. No other medication or antibiotics were given.

\section{Evaluation}

Flap survival was assessed at the end of the first postoperative week in all animals. While the rats were under anesthesia, the flaps were traced on acetate paper, and the area of necrosis was marked. The area of necrosis and total flap area were measured using a polar planimeter. The surface area of flap necrosis, represented by the blackened and indurated area of the cephalad part of the flap, was calculated using the planimeter, and the result for each flap was expressed as percentage survival (ie, surviving flap area/total flap area $\times 100$ ). Values are expressed as means \pm SEM. The student's $t$ test was applied to the statistical analysis of independent samples, comparing the control group with each of the treated groups. Probabilities of less than 0.01 were accepted as significant. Minitab statistical software (Minitab Inc, USA) was used for statistical calculations.

\section{RESULTS}

None of the flaps was lost due to hematoma, infection or cannibalism. Control group rats treated with saline (placebo) had a percentage mean survival area of 69.92 (SEM=0.45) (Figure 1). Positive controls receiving theophylline (group V), which selectively antagonizes the beneficial effects of adenosine, had a significantly lower flap survival area $(\mathrm{P}<0.05)$, with a percentage mean survival area of 70.42 (SEM=0.85) (Figure 1). Rats receiving standard (group III) and high doses of adenosine (group IV) showed significantly increased flap survival compared with theophylline-treated flaps $(\mathrm{P}<0.01)$

Low dose adenosine did not enhance the viability of random flaps, and flap survival was significantly less than that seen with standard and high dose adenosine-treated flaps, with a percentage mean survival area of $70.92(\mathrm{SEM}=0.57)$ 


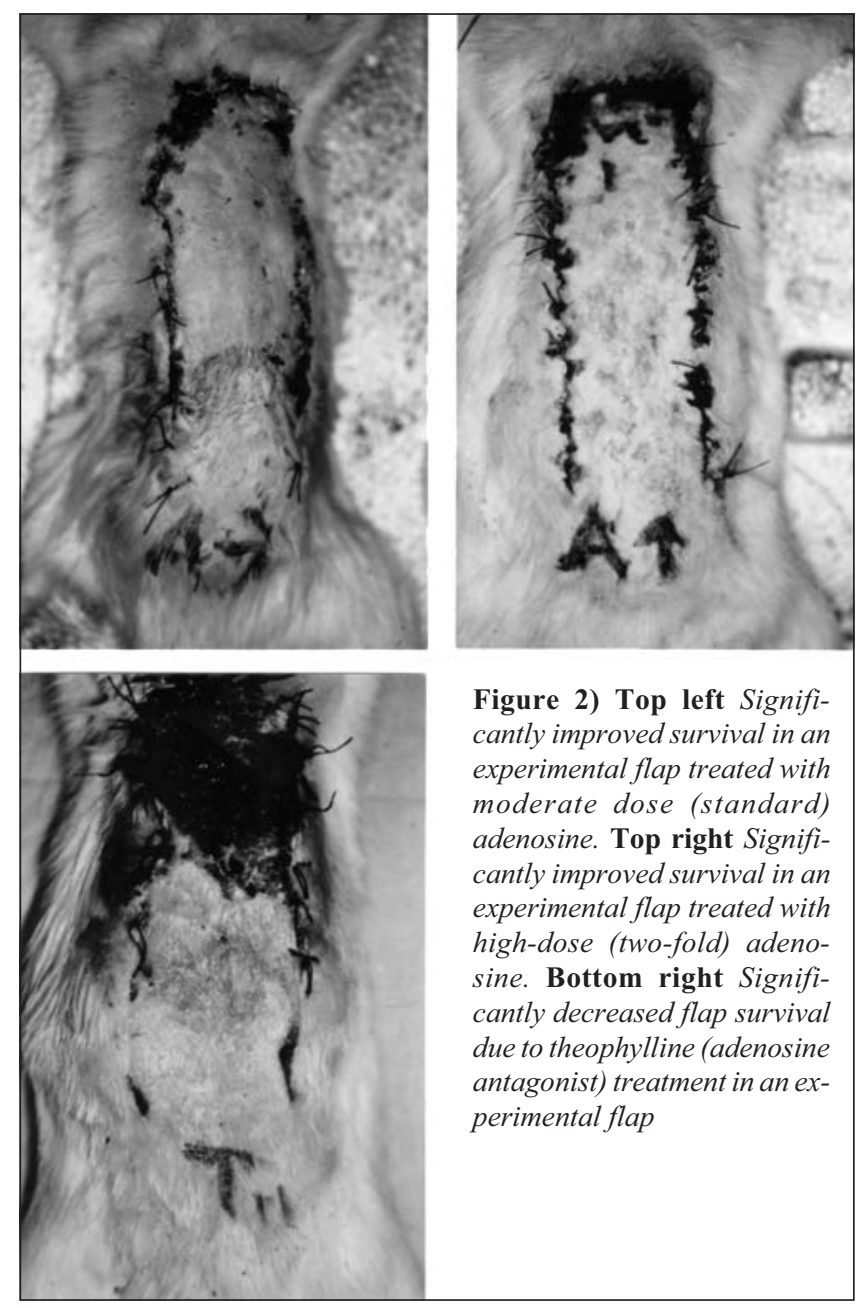

(Figure 2). Comparison of low dose adenosine-treated flaps with the flaps of controls yielded an insignificant difference in survival $(\mathrm{P}=0.18)$. Standard (group III) and high dose adenosine-treated (group IV) flaps showed a significantly augmented flap survival with mean survival areas of 84.0 $(\mathrm{SEM}=0.72)$ and $85.0(\mathrm{SEM}=0.61)$, respectively (Figure 2). There was no significant difference between groups III and IV in mean survival rate $(\mathrm{P}=0.383)$. Surviving percentage areas of the flaps in groups I to $\mathrm{V}$ are listed in Figure 3.

\section{DISCUSSION}

The present research has generated several observations. Specifically, therapeutic (standard) and two-fold high doses of intravenous adenosine administration were effective in augmenting flap survival in random-pattern flaps in the rat. It was also observed that this salutary effect of adenosine against necrosis in random dorsal flaps was reversed by an adenosine antagonist, 8-phenyltheophylline, that caused a necrosis pattern similar to that of untreated controls. Furthermore, the beneficial effect of adenosine seems to be doserelated because no enhanced flap survival was shown with low dose adenosine (Figures 2,3). The caudally-based, $3 \times 10$ $\mathrm{cm}$ sized, random flap in the rat was selected as the experimental model because its consistency and standardization

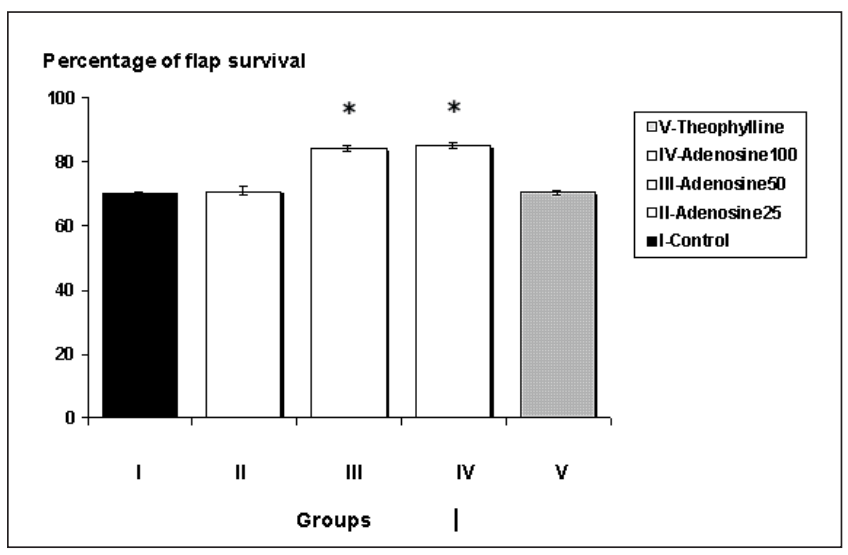

Figure 3) A comparison of the values for mean per cent flap survival among the various doses of adenosine $(25,50$ and $100 \mu \mathrm{g} / \mathrm{kg} /$ day $)$, theophylline $\left(10 \mathrm{mg} / \mathrm{kg} /\right.$ day) and the control group $(1 \mathrm{~mL} /$ day $)$. ${ }^{*} P<0.01$ Percentage survival of flaps

were validated by Khouri et al (9). Area and pattern of flap necrosis in the control animals receiving saline were in conformation with previous studies.

A large body of evidence suggests that adenosine can protect the heart against ischemia and/or reperfusion injury $(11,12)$. Many studies have shown that the activation of adenosine $\mathrm{A}_{1}$-receptors showed an ischemic 'preconditioning' effect to reduce infarct size, and the blockade of these receptors abolished this effect $(13,14)$. Pretreatment with adenosine has been reported to stimulate glycolysis in hypoxic hearts and delay the onset of ischemic contracture $(15,16)$. The protective effect of adenosine in myocardial ischemia is achieved by regulating the myocardial oxygen supply-demand balance. During the period of oxygen deprivation, adenosine augments energy production through increased glycolytic flux and, during reperfusion, revives cellular energy charge via purine salvage pathways $(17,18)$. Adenosine displays a receptor-mediated cardioprotective effect, and the activation of $\mathrm{A}_{1}$-receptors couples a variety of effector systems in the myocardium. Activated $\mathrm{A}_{1}$-receptors can couple to adenylate cyclase through an inhibitory G-protein, resulting in the inhibition of the conversion of ATP to cyclic adenosine monophosphate, resulting in preservation of ATP stores (18). These activated $\mathrm{A}_{1}$-receptors can also couple to ATP-sensitive potassium ion $\left(\mathrm{K}_{\mathrm{ATP}}\right)$ channels, probably by enhancing the channel sensitivity to ATP. Opening of $\mathrm{K}_{\mathrm{ATP}}$ channels results in the increase of potassium ion influx and membrane hyperpolarization, thereby reducing the opening time for voltage-dependent calcium channels and, thus, resulting in the shortening of action potentials and slowing of cellular ATP catabolism, and increasing myocardial ischemic tolerance $(19,20)$. Forrest and colleagues (7) showed that preischemic adenosine treatment is effective in the augmentation of ischemic tolerance in muscle flaps, and this protective effect was attributed to the activation of $\mathrm{A}_{1}$-receptors and $\mathrm{K}_{\mathrm{ATP}}$ channels, resulting in diminished metabolism and slowed ATP consumption.

Besides its direct effect on myocytes, adenosine has been 
shown to attenuate noradrenalin release from sympathetic nerves during early ischemia and antagonize the positive inotropic effect of catecholamines mediated via the adenylyl cyclase system (10). These effects would compromise the oxygen demand of the flap during ischemia and decrease the rate of ATP degradation. The inhibition of noradrenalin may be another mechanism through which adenosine has augmented random flap survival in the rat because sympathetic regulation of the circulation within the flap was shown to have a significant role in the maintenance of flap survival $(21,22)$. Furthermore, adenosine $\mathrm{A}_{2}$-receptors stimulate adenylate cyclase through a stimulatory G-protein, causing myocardial vasodilation $(17,23)$. Vasodilation that resulted from adenosine $\mathrm{A}_{2}$-receptor stimulation may also be beneficial in increasing critical blood supply to the flap before and after ischemia, thus increasing the surviving area.

Adenosine has also been shown to inhibit superoxide anion production from neutrophils, and inhibit platelet aggregation and microthrombi formation in the capillaries $(24,25)$. Beneficial effects of prevention or clearance of free oxygen radicals in states of ischemia have been shown in several studies, and enhanced flap survival in the present study can be attributed to this effect of adenosine, whereas inhibition of platelet aggregation and antithrombotic treatment have been shown to decrease distal flap necrosis in numerous studies $(26,27)$. Minamino et al (28) have shown that adenosine treatment inhibits leukocyte-induced vasoconstriction by inhibiting the adhesion of neutrophils to the endothelium via the stimulation of $\mathrm{A}_{2 \mathrm{a}}$-receptors. This effect can be linked to the inhibition of lipid peroxidation by adenosine to contribute to the flap survival, and finally, adenosine receptor activation has been shown to stimulate the induction of vascular endothelial growth factor - a factor that has been shown to enhance flap survival through neovascularization. Though the 'graft effect' of the bed at the flap-bed interface is controversial, many studies that have used systemic or topical factors that trigger neovascularization have been proved to be salutary on random flap survival, so, apart from its direct vascular effects, adenosine can be hypothesized to enhance the revascularization of the severely-ischemic distal random segment of the flap $(29,30)$.

In the present experiment, adenosine, which is also used clinically as a coronary vasodilator, was hypothesized to show a beneficial effect by decreasing distal flap necrosis because adenosine was previously shown to increase tolerance to ischemia in the myocardium and skeletal muscle. Flap survival was clearly enhanced by adenosine in varying doses, and to double-check the hypothesis, a selective adenosine antagonist, phenyltheophylline, which was shown to reverse and abolish the preconditioning and cardioprotective effects of adenosine in myocardium, was also administered (31). 8-phenyltheophylline strongly abolishes the vasodilatory effect of adenosine and adenosine $5^{\prime}$-diphosphate through $\mathrm{P} 2 \mathrm{Y} 1$ receptors and decreases total coronary resistance in rats (5).

The mechanisms underlying the success of adenosine in reducing flap necrosis was not the main goal of the present study and, therefore, these mechansims were not investigated. To the authors' knowledge, the present study is the first to investigate the use of adenosine in a field other than myocardial ischemia or muscle flaps. It is most likely that adenosine exerts its salutary effect through the combined inhibition of ATP catabolism, noradrenalin release, inhibition of lipid peroxidation, increased release of vascular endothelial growth factor and, most importantly, vasodilation. Further studies are required to delineate the exact basis for this salutary effect on random flap survival in rats. These findings support another clinical use of adenosine for flap salvage apart from its use in the salvation of ischemic heart disease.

\section{REFERENCES}

1. Kerrigan CL. Skin flap failure: Pathophysiology. Plast Reconstr Surg 1983;72:766-74.

2. Cuono CB, Marquetand R, Klein MB, Armitage I. Critical role of phosphagens in the energy cascade of cutaneous ischemia and protective action of phosphocreatine analogues in skin flap survival. Plast Reconstr Surg 1998;101:1597-603.

3. Lille S, Boyle EM Jr, Schoeller T, Suchy H, Russell RC. Augmentation of cAMP improves muscle-flap survival and tissue inflammation in response to ischemia/reperfusion injury. J Reconstr Microsurg 1999;15:37-45.

4. Fox IH, Kelley WN. The role of adenosine and 2-deoxyadenosine in mammalian cells. Ann Rev Biochem 1978;47:655-86.

5. Korchazkina O, Wright G, Exley C. Intravascular ATP and coronary vasodilation in the isolated working heart. Br J Pharmacol 1999;127:701-8.

6. Sollevi A, Lagerkranser M, Irestet L, Gordon E, Lindquist C. Controlled hypotension with adenosine in cerebral aneurysm surgery. Anesthesiology 1984;61:400-5.

7. Forrest CR, Neligan P, Zhong A, He W, Yang RZ, Pang CY. Acute adenosine treatment is effective in augmentation of ischemic tolerance in muscle flaps in the pig. Plast Reconstr Surg 1997;99:172-82.

8. Toombs CF, McGee DS, Johnston WE, Vinten-Johansen J. Myocardial protective effects of adenosine: Infarct size reduction with pretreatment and continued receptor stimulation during ischemia. Circulation 1992;86:986-94.

9. Khouri RK, Angel MF, Edström LE. Standardizing the dorsal rat flap. Surg Forum 1986;37:590-1.

10. Richardt G, Waas W, Kranzhofer R, Cheng B, Lohse MJ, Schomig A. Interaction between the release of adenosine and noradrenaline during sympathetic stimulation: A feed-back mechanism in rat heart. J Moll Cell Cardiol 1989;21:269-77.

11. Liu GS, Thornton J, Van Winkle D, Stanley AWH, Olsson RA, Downey JM. Protection against infarction afforded by preconditioning is mediated by $\mathrm{A}_{1}$ adenosine receptors in rabbit heart. Circulation 1991;84:350-6.

12. Yao Z, Gross GJ. A comparison of adenosine-induced cardioprotection and ischemic preconditioning in dogs: Efficacy, time course, and role of $\mathrm{K}_{\text {ATP }}$ channels. Circulation 1994;89:1229-36.

13. Downey JM, Cohen MV, Ytrehus K, Liu Y. Cellular mechanisms in ischemic preconditioning: The role of adenosine and protein kinase $\mathrm{C}$. Ann N Y Acad Sci 1994;723:82-98.

14. Babbitt DG, Virmani R, Forman MB. Intracoronary adenosine administered after reperfusion limits vascular injury after prolonged ischemia in the canine model. Circulation 1989;80:1388-99.

15. Wyatt DA, Edmunds MC, Rubio R, Berne RM, Lasley RD, Mentzer R. Adenosine stimulates glycolytic flux in isolated perfused rat hearts by A 1 -adenosine receptors. Am J Physiol 1989;257:H1952-7.

16. Lasley R, Rhee J, Van Wylen D, Mentzer R. Adenosine $A_{1}$ receptor mediated protection of the globally ischemic isolated rat heart. J Moll Cell Cardiol 1990;22:39-47.

17. Ely SW, Berne RM. Protective effects of adenosine in myocardium ischemia. Circulation 1992;85:893-904. 
18. Romano FD, MacDonald SG, Dobson JG. Adenosine receptor coupling to adenylate cyclase of rat ventricular myocyte membranes. Am J Physiol 1989;257:H1088-95.

19. Cole WC, McPherson CD, Sontag D. ATP-regulated $\mathrm{K}^{+}$channels protect the myocardium against ischemia reperfusion damage. Circ Res 1991;69:571-81.

20. McPherson CD, Pierce GN, Cole WC. Ischemic cardioprotection by ATP-sensitive $\mathrm{K}^{+}$channels involves high energy phosphate preservation. Am J Physiol 1993;265:H1809-18.

21. Jurell G, Jonsson CE. Increased survival of experimental skin flaps in rats following treatment with antiadrenergic drugs. Scand J Plast Reconstr Surg 1976;10:169-72.

22. Kay SR, LeWinn LR. Neural influences on experimental flap survival. Plast Reconstr Surg 1981;67:42-8.

23. Belardinelli L, Linden J, Berne RM. The cardiac effects of adenosine. Prog Cardiovasc Dis 1989;32:73-97.

24. Schrier DJ, Imre KM. The effects of adenosine agonists on human neutrophil function. J Immunol 1986;137:3284-9.

25. Kitakaze M, Hori M, Sato H, et al. Endogenous adenosine inhibits platelet aggregation during myocardial ischemia in dogs. Circ Res 1991;69:1402-8

26. Suzuki S, Miyachi Y, Niwa Y, Isshiki N. Significance of reactive oxygen species in distal flap necrosis and its salvage with liposomal SOD. Br J Plast Surg 1989;42:559-64.

27. Nichter LS, Sobieski MW, Edgerton MT. Augmentation of critical skin flap survival following ibuprofen therapy. Ann Plast Surg 1986;16:305-12.

28. Minamino T, Kitakaze M, Node K, et al. Adenosine inhibits leukocyte-induced vasoconstriction. Am J Physiol 1996;271:H2622-8.

29. Grant MB, Tarnuzzer RW, Caballero S, et al. Adenosine receptor activation induces vascular endothelial growth factor in human retinal endothelial cells. Circ Res 1999;85:699-706.

30. Kryger Z, Zhang F, Dogan T, et al. The effects of VEGF on survival of a random flap in the rat: examination of various routes of administration. Br J Plast Surg 2000;53:234-9.

31. Daly JW, Padgett W, Shamim MT, Butts-Lamb P, Walters J. 1,3-Dialkyl-8-(p-sulfophenyl)xantines: potent water soluble antagonists for A1- and A2-adenosine receptors. J Med Chem 1985;28:487-92. 